\title{
Rainstorms able to induce flash floods in a Mediterranean-climate region (Calabria, southern Italy)
}

\author{
O. G. Terranova ${ }^{1}$ and S. L. Gariano ${ }^{1,2}$ \\ ${ }^{1}$ Italian National Research Council, Research Institute for Geo-hydrological Protection (CNR-IRPI), via Cavour 6, \\ 87036 Rende (CS), Italy \\ ${ }^{2}$ Department of Physics and Geology, University of Perugia, via A. Pascoli, 06123 Perugia, Italy \\ Correspondence to: S. L. Gariano (gariano@irpi.cnr.it)
}

Received: 19 December 2013 - Published in Nat. Hazards Earth Syst. Sci. Discuss.: 10 March 2014

Revised: - - Accepted: 29 July 2014 - Published: 10 September 2014

\begin{abstract}
Heavy rainstorms often induce flash flooding, one of the natural disasters most responsible for damage to manmade infrastructures and loss of lives, also adversely affecting the opportunities for socio-economic development of Mediterranean countries. The frequently dramatic damage of flash floods are often detected, with sufficient accuracy, by post-event surveys, but rainfall causing them are still only roughly characterized. With the aim of improving the understanding of the temporal structure and spatial distribution of heavy rainstorms in the Mediterranean context, a statistical analysis was carried out in Calabria (southern Italy) concerning rainstorms that mainly induced flash floods, but also shallow landslides and debris flows. Thus, a method is proposed - based on the overcoming of heuristically predetermined threshold values of cumulated rainfall, maximum intensity, and kinetic energy of the rainfall event - to select and characterize the rainstorms able to induce flash floods in the Mediterranean-climate countries. Therefore, the obtained (heavy) rainstorms were automatically classified and studied according to their structure in time, localization, and extension. Rainfall-runoff watershed models can consequently benefit from the enhanced identification of design storms, with a realistic time structure integrated with the results of the spatial analysis. A survey of flash flood events recorded in the last decades provides a preliminary validation of the method proposed to identify the heavy rainstorms and synthetically describe their characteristics. The notable size of the employed sample, including data with a very detailed resolution in time that relate to several rain gauges welldistributed throughout the region, gives robustness to the obtained results.
\end{abstract}

\section{Introduction}

Many regions belonging to the Mediterranean Basin are prone to a large number of catastrophic geo-hydrological events with loss of life, injuries, and high economic and social impact (Jansà et al., 1994; Siccardi, 1996; Gaume et al., 2009). During the period 1960-2009, 298 floods occurred in current EU member states (www.emdat.be), resulting in almost 5500 casualties, and resulting in close to USD 106 billion in damage. A total of 33 of the floods were categorized as "flash floods", 81 as a "flood", and 184 as a "general flood". More recently, the event that affected the Italian regions Sardinia and Calabria on 18 and 19 November 2013 (caused by the well-known cyclone Cleopatra), produced 16 fatalities and overall losses quantified in USD 780 thousands (Munich RE, 2014).

In recent decades, because of climate change, both violence and the frequency of torrential rain events (i.e. $>64 \mathrm{~mm} \mathrm{~d}^{-1}$ ) are increased (Alpert et al., 2002), despite the decrease of the annual rainfall in the Mediterranean Basin (Piervitali et al., 1998). Analysing rainfall patterns Lionello et al. (2006) have highlighted a huge spatial and temporal variability of precipitation in the Mediterranean Basin. In Italy, Brunetti et al. (2004) detected a significant decrease in both annual precipitation and annual number of wet days, and an increase in the precipitation intensity. Working at regional scale, Brunetti et al. (2012) found a significant negative trend of total annual precipitation in Calabria (southern Italy) over the period 1923-2006. With regards to the monthly total precipitation, they detected a general negative trend, albeit not 
significant everywhere, for the autumn-winter period, and a slight increase in the total summer precipitation.

Flash floods occur when, over a few hours, heavy rainfall events affect, with hundreds of millimetres of rain, small basins (Creutin and Borga, 2003; Collier, 2007; Younis et al., 2008). In the Mediterranean-climate regions, low permeability and highly erodible soils often characterize these small basins (typically below a few hundred $\mathrm{km}^{2}$ ), whose slopes are often very steep and susceptible to landslides. Ultimately, the runoff times of the basins considerably favours the formation of flash floods due to the processes of runoff with a very fast response (Creutin et al., 2009). The huge damage caused by flash floods are also notable due to the high content of solid material (including floating materials such as timber) from the riverbed and from soil slips and mud/debris flows that take place on the slopes. The potential for damage of flash floods is mostly due to the high population density of the Mediterranean coastal regions. Even in the face of increasingly more precise weather forecasting for civil protection purposes, it is still very difficult to predict, with adequate accuracy, the areas that will be struck by these catastrophic events. Then, special attention is given to the study of spatial and temporal variability of rainfall, as these basins are very rarely equipped with sensor networks (and/or monitored by weather radar), dedicated to the direct measurement of the parameters related to the physical processes of interest. In fact, being the hydrological response controlled by rainfall, proper understanding, interpreting and forecasting of spatial and temporal variability of rainfall events is a prerequisite for the adoption of appropriate mitigation measures and reducing the connected risk. On the other hand, watershed models are increasingly complex and require more detailed precipitation input to drive the hydrologic processes to be satisfactorily simulated. This input is rarely available at the appropriate time scale (at the order of minutes) and does not have sufficient coverage in space.

Because of its geographical location, its topography and for its mountainous nature - with mountain ranges perpendicular to the direction of the main wet currents - despite its small size, Calabria is affected by rains highly variable in both time and space (Terranova and Iaquinta, 2011). Thus, Calabrian territory appears adequate to represent the characteristics of rainfall of many geographical areas of the Mediterranean Basin.

The present study is an attempt to improve, from a statistical point of view, the understanding at sub-hourly scale of the temporal and spatial structure of intense rainfall events that have hit Calabria, inducing mainly flash floods, but also shallow landslides and debris flows.

\section{Geographical framework and climatic outlines}

Calabria (Fig. 1) is a long and narrow peninsula, covering an area of about $15080 \mathrm{~km}^{2}$ and stretching from north to south

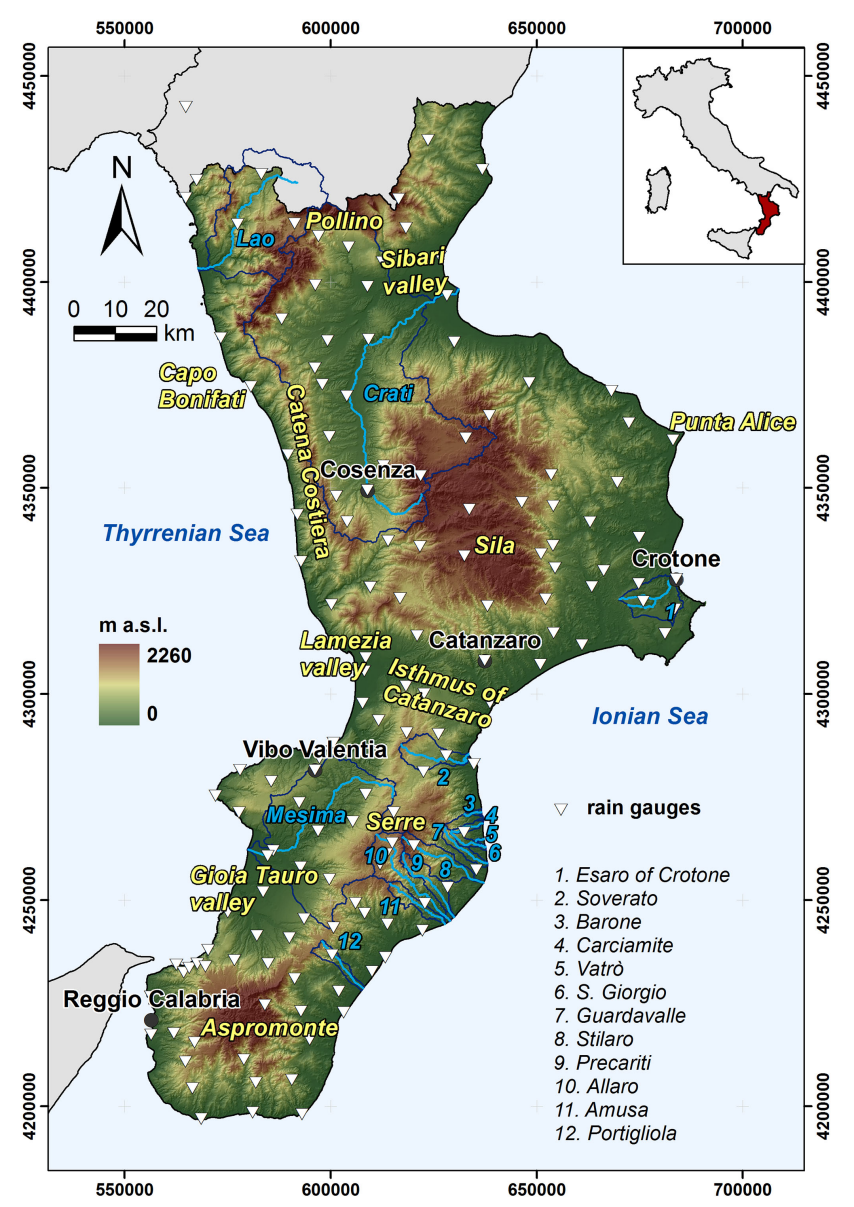

Figure 1. Geographical framework of Calabria (southern Italy). The orographic map also includes: (black) indications of the main towns; (yellow) mountain ranges and place names mentioned in the text; (blue) main river and fiumare recently affected by flash floods and main rivers (labelled). White triangles indicate the considered rain gauges.

for $248 \mathrm{~km}$. It is bounded by the Tyrrhenian Sea, on the western side, and by the Ionian Sea, on the southern and eastern sides.

Five main ridges mark, from north to south and with maximum altitudes varying from 1500 to $2000 \mathrm{~m}$ a.s.l., the topography of Calabria: Pollino, Catena Costiera, Sila, Serre, and Aspromonte. These mountains have very steep slopes; in fact, starting from sea level, only a few tens of kilometres are needed to reach the highest altitudes. The narrowest part of the Calabrian peninsula is the Isthmus of Catanzaro (a gap between the southern end of Sila and the northern part of the Serre mountain ridges) that is approximately $31 \mathrm{~km}$ in width. The maximum width, between Punta Alice and Capo Bonifati, is ca. $111 \mathrm{~km}$.

Calabria, because of its rugged orography, has a large number of small drainage basins. Only a small part of their courses flows on plains. In particular, rivers that originate from the Catena Costiera have very pronounced slopes. In 
fact, the extension of the Tyrrhenian side is less than the Ionian one (Fig. 1). On the former side, only two streams have the hydrological regime of a river: the Lao River, due to the large number of karstic springs in its basins; and the Mesima River, because of its extension. On the Ionian side, the Crati River flows in a tectonic graben draining the largest basin in Calabria, collecting waters coming from surrounding mountains and forming the Plain of Sibari. Other relatively large rivers drain the eastern side of Sila Massif. In the northern and southern parts of the Ionian side of Calabria, a great deal of ephemeral streams with typical braided riverbeds drains the steep slopes of the mountains and reaches the sea after passing a narrow hilly belt. These streams are the Calabrian fiumare (Fairbridge, 1968; Sorriso-Valvo and Terranova, 2006), that (like most other small Calabrian streams) have a hydrological regime closely correlated with rainfall, also for the reason of the low permeability of soils. Then, in the absence of direct hydrometric measurements, the peak discharge rates can be estimated only based on sub-hourly rainfall.

In Calabria, an average yearly rainfall of $1150 \mathrm{~mm}$ corresponds to noticeable seasonal contrasts and to a high variability over Calabria. The eastern side is less rainy than that in west, especially as the disturbances come frequently from the west and discharge some of their rain on the Sila Plateau whilst moving towards the east. The Catena Costiera and the Serre mountain ranges are rainier than the Sila Plateau, partially shielded from the first mountain range. Yearly average precipitation is $>2000 \mathrm{~mm}$ on the Catena Costiera and the Aspromonte Massif, whereas precipitation on the Ionian mountain slopes is $600-1000 \mathrm{~mm}$, with values of $\sim 500 \mathrm{~mm}$ along the coastal plains. With reference to seasonality, the abundant rains during autumn and winter (more than $70 \%$ of yearly total precipitation falls from October to March) along the Tyrrhenian slopes and, more heavily, on the Ionian side, must be highlighted (Terranova, 2004). These features and snowfall in the mountains contrast with subtropical climatic conditions in the valley and along some stretches of coast.

Coastal mountains strongly influence the precipitation regime, because of the fronts and convective cells ascending their steep seaside slopes. Föhn blows to the lee-side of the mountain chains, causing drier and warmer climate in the largest valleys. In all seasons, low-pressure conditions cause intense and prolonged rainstorms brought by warm fronts approaching from the SE, bringing red silt-rich rains and very uncomfortable, warm, and wet Scirocco conditions. Cold fronts from the Icelandic zone may reach Calabria from the NW, especially in winter, with high intensity rainfall. In the short spring, the weather is highly unstable with scarce and drizzly rainfall. In summer, strong convective rainstorms are frequent; sometimes small tornados may form on the sea that may reach inland. In autumn, Siberian cold fronts that may approach from the NE cause intense precipitations. Cold fronts, approaching Calabria from the NW in winter, are the cause of extremely intense rains and, in some cases, of a thick snow cover that may also form at low elevations (SorrisoValvo and Terranova, 2006; Terranova et al., 2009).

With regards to annual maxima of high-intensity and short-duration rainfall, Versace et al. (1989) delimited three homogeneous rainfall regions in Calabria, including: (i) a Tyrrhenian region (T, $25.8 \%$ of the region) along the western Tyrrhenian coast, (ii) a Central region ( $\mathrm{C}, 44.3 \%$ ), comprising the mountain ranges along the main divide, and (iii) an Ionian region along the eastern Ionian coast (I, 29.9\%). They found that the Tyrrhenian rainfall region is characterized by more frequent and less severe rainfall events than the Ionian rainfall region, whereas the Central rainfall region has events with intermediate characteristics.

The main part of Calabria is characterized by a typically Mediterranean climate ( $\mathrm{Cs} a$ - Hot-summer Mediterranean climate) in Köppen's (1948) classification, with dry and hot summers and low average temperatures. The remaining portions (inland and not valley areas) are classified as $C s b$, or $C f b$, or $C f a$ (Warm summer Mediterranean, or Maritime Temperate, or Humid subtropical climate, respectively - cf. Iaquinta and Terranova, 2010).

As an average, temperature features of Calabria are summarized as follows: (i) the annual values range from $10^{\circ} \mathrm{C}$ on the mountain slopes to $18^{\circ} \mathrm{C}$ along the coast; (ii) August is the hottest month and January the coldest; (iii) the daily values may exceed $40^{\circ} \mathrm{C}$ in July and August; (iv) January presents $10^{\circ} \mathrm{C}$ along the coasts and $4^{\circ} \mathrm{C}$ in the mountains; (v) values below $0^{\circ} \mathrm{C}$ may often occur on Sila and Aspromonte (Terranova et al., 2009).

\section{Rainfall data and rainfall events}

Thanks to the availability of observations with high temporal detail ( $5 \mathrm{~min}$ ) related to 155 sites (one rain gauge per less than $100 \mathrm{~km}^{2}$ ), a considerable amount of rainfall series were analysed in order to contribute to the quantitative and qualitative characterization of extreme events affecting Calabria.

To identify a single rainfall event, many criteria could be adopted, aimed at determining the time-span between the end and the beginning of two consecutive individual rainfall events. The classification of events on a meteorological basis shows that, in a small basin, events can be characterized by widely differing duration and extension (Houze, 1969). In the same way, a statistical analysis of rainfall time series allows us to distinguish events which are independent of one another without, however, contributing very much to the aim of the present study (see, among others, RestrepoPosada and Eagleson, 1982). The choice of the authors was based on average characteristics of watersheds in Calabria in relation to the process of flash flood development (Colosimo et al., 1996; Joo et al., 2014). Based on the size of these watersheds, values roughly ranging from 1 to $12 \mathrm{~h}$ may be assumed as the time period from the end of a rainfall event to the end of its direct contribution to surface runoff. Then 
a minimum value of $6 \mathrm{~h}$ seems reasonable in order to ensure that significant surface runoff cannot be added to either of two subsequent events. This criterion is consistent with that proposed by Wischmeier and Smith (1978), and since the flash floods are usually characterized by a considerable amount of sediments resulting from the dismantling of the slopes, rainstorms were selected that, according to these authors, are to be considered erosive.

In more detail, distinguishing individual rainstorms as rainy periods separated by at least $6 \mathrm{~h}$ of dry weather (Wischmeier and Smith, 1978), the study initially considers more than 152 thousands rainstorms, having different durations, recorded in different seasons between 1989 and 2008 at 155 rain gauges in Calabria. Accordingly, 45533 erosive rainstorms, including 27111 rainstorms with rainfall amount $\left(P_{\mathrm{EV}}\right)$ greater than $12.7 \mathrm{~mm}$, and 18422 having $P_{\mathrm{EV}} \leq 12.7 \mathrm{~mm}$ but exceeding $6.35 \mathrm{~mm}$ in $15 \mathrm{~min}$, were selected as relevant and analysed.

\section{Preliminary analysis of rainstorms}

An analysis was carried out to characterize, in a simple but effective way, the rainfall events with regard to magnitude, frequency, locations, temporal structure and pattern, season of occurrence. In this phase of the study, the analysis does not refer to areal rainstorms. The 45533 selected rainfall events

1. have $P_{\mathrm{EV}}$ comprised between 6.4 and $602.2 \mathrm{~mm}$, with a mean value of $23.5 \mathrm{~mm}$;

2. last from durations, $D_{\mathrm{EV}}$ equal to $10 \mathrm{~min}$ to approximately 10 days, with a mean value of $\sim 15 \mathrm{~h}$;

3. range from negligible values of maximum rainfall intensity in $30 \mathrm{~min}, I_{30}$, up to $154.8 \mathrm{~mm} \mathrm{~h}^{-1}$, with mean value $11.6 \mathrm{~mm} \mathrm{~h}^{-1}$;

4. have energy, $E_{J}$, ranging from 0.83 to $\sim 138 \mathrm{MJ} \mathrm{ha}^{-1}$, with mean value of $\sim 4.6 \mathrm{MJ} \mathrm{ha}^{-1}$.

The temporal storm structure was described as cumulative percentages of storm rainfall and storm duration, by means of the standardized rainfall profiles (SRPs) (Huff, 1967, 1990), allowing and simplifying the analysis, presentation and comparison of data. Moreover, Huff's study adopts the definition of "rainfall event" proposed by Wischmeier and Smith (1978) and it is adopted in this work. The main attraction of the use of SRP lies in the fact that it is based on actual data of regional precipitation; its weak point is that large samples of data are required to obtain regional profiles. The analysis of the SRP can be performed to disaggregate the precipitation totals or even to derive other types of information. At this purpose, the rainfall events can be classified according to various criteria: duration, total rainfall, maximum intensity in a fixed time or average intensity, energy of the storm, geographical area of occurrence, etc. In
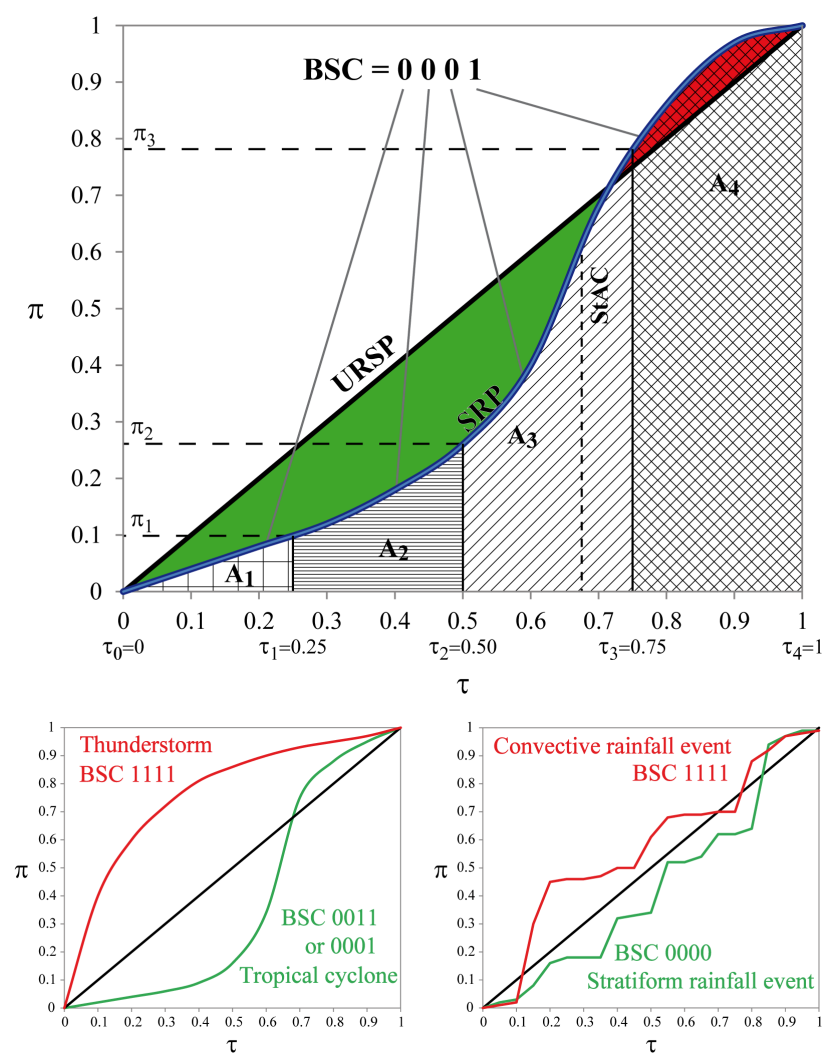

Figure 2. Top: elements of a standardized rainfall profile (SRP). URSP = Uniform SRP; StAC = Storm Advancement Coefficient; $\mathrm{BSC}=$ binary shape code. On the vertical axis, $\pi$ represents the normalized cumulative depth of the rainstorm; on the horizontal axis, $\tau$ represents the cumulative fraction of the rainstorm time (from Terranova and Iaquinta, 2011 - modified). Bottom left: binary shape codes, BSC, associated to the idealized structure of thunderstorms and of tropical cyclones. Bottom right: binary shape codes, BSC, associated to the recorded structure of convective and stratiform rainfall events in the Brue Basin, south-west England (from Moore et al., 2005 - modified).

further detail, the proposal of Terranova and Iaquinta (2011) was adopted to better identify, in an automated environment, the shape of the profile (Fig. 2) based on the comparison between the areas $A_{1}, A_{2}, A_{3}$, and $A_{4}$ - underlying the four quarters of durations of the SRP, relative to each single event - with the corresponding four values of the uniform SRPs (URSPs). More precisely, a 4-digit binary shape code, BSC, was determined as follows: the generic $k$ th $(k=1,2,3,4)$ threshold was defined corresponding to the area $A_{k}^{*}$ underlying the four quarters of the uniform SRP: $A_{k}^{*}=\frac{1}{2} \tau_{k}^{2}-A_{k-1}^{*}$, with $A_{0}^{*}=0$, and $\tau_{1}=0.25, \tau_{2}=0.50, \tau_{3}=0.75, \tau_{4}=1$. The analogous four values of the area $A_{k}$ underlying the generic SRP were compared to $A_{k}^{*}$ obtaining the binary shape code (BSC) $=S_{1} S_{2} S_{3} S_{4}$, based on the logical condition: if $A_{k}>A_{k}^{*}, S_{k}=1$; vice versa $S_{k}=0$. As a result, a BSC was associated with each SRP. The informative content expressed 

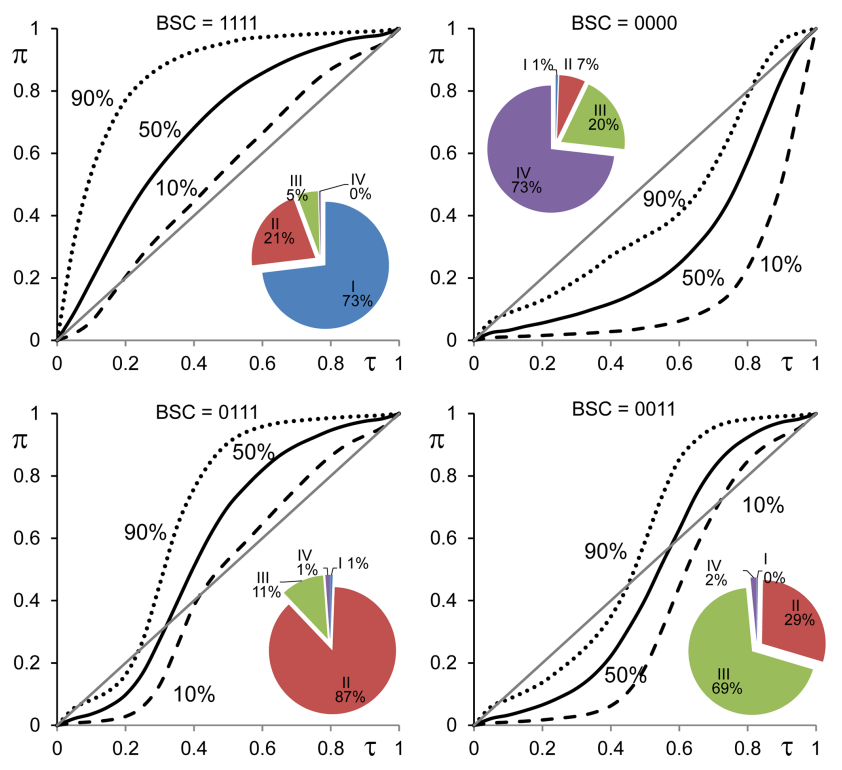

Figure 3. Standardized rainfall profiles (SRPs) relative to the 90th, 50th, and 10th fractiles of the four most numerous BSC in Calabria. In the insets, with reference to each BSC, Huff's quartiles are also distinguished. On the vertical axis, $\pi$ represents the normalized cumulative depth of the rainstorm; on the horizontal axis, $\tau$ represents the cumulative fraction of the rainstorm time.

by the BSC is more complete than that expressed by Huff's quartiles. BSC describes the profile as a whole, while Huff's quartiles describes only a quarter of duration, but does not depict the rest of the profile.

In Fig. 3, the BSC classification of the four most numerous SRPs recorded in Calabria are reported, also distinguishing them according to Huff's quartiles. Only 8 of 16 types of BSC occur with frequencies higher than $2 \%$. Statistical analyses showed that SRPs corresponding to the eight remaining BSCs do not possess, on average, high values of $P_{\mathrm{EV}}$, $D_{\mathrm{EV}}, I_{30}$. The SRP with $1111 \mathrm{BSC}$, typical of thunderstorms (Fig. 2), occurs in over a third of the examined events, as reported in Terranova and Iaquinta (2011). By means of the BSC and the SRP, Fig. 2 aims at comparing the structures of a theoretical thunderstorm and of a convective event recorded in south-west England. The thunderstorms are a particular case of convective storms, meteorologically associated to cumulonimbus. That aside, sometimes the thunderstorms are included in a mesoscale convective system, whose rainfall is typically derived from convective clouds and from stratiform clouds. The same BSC describes the two rainfall structures.

To introduce the topics that will be discussed in the next paragraphs, the most severe $2 \%$ of the 45533 erosive events were selected. In more detail, 903, 909, and 909 events were detected and characterized respectively by $P_{\mathrm{EV}} \geq 100 \mathrm{~mm}$, $I_{30} \geq 44 \mathrm{~mm} \mathrm{~h}^{-1}$, and $E_{J} \geq 20 \mathrm{MJ} \mathrm{ha}^{-1}$. Focusing on rainstorms characterized by $P_{\mathrm{EV}} \geq 100 \mathrm{~mm}$, they result in being characterized by the $I_{30}, E_{J}$ and $D_{\mathrm{EV}}$ values reported in Ta-
Table 1. Statistical features of the 903 rainfall events that have $P_{\mathrm{EV}} \geq 100 \mathrm{~mm}$.

\begin{tabular}{lrrrr}
\hline & $\begin{array}{r}P_{\mathrm{EV}} \\
{[\mathrm{mm}]}\end{array}$ & $\begin{array}{r}I_{30} \\
{\left[\mathrm{~mm} \mathrm{~h}^{-1}\right]}\end{array}$ & $\begin{array}{r}E_{J} \\
{\left[\mathrm{MJ} \mathrm{ha}^{-1}\right]}\end{array}$ & $\begin{array}{r}D_{\mathrm{EV}} \\
{[\mathrm{dd}: \mathrm{hh}: \mathrm{mm}]}\end{array}$ \\
\hline Average & 152.8 & 33.52 & 32.27 & $1: 22: 05$ \\
Standard deviation & 61.5 & 23.34 & 14.65 & $1: 16: 37$ \\
Minimum & 100.0 & 0.40 & 16.73 & $4: 25$ \\
Maximum & 602.2 & 154.80 & 137.94 & $10: 04: 50$ \\
\hline
\end{tabular}

ble 1. Regarding the comparisons shown in Fig. $4 a-d$, just the SRP relative to $I_{30}<44$ and $I_{30} \geq 44 \mathrm{~mm} \mathrm{~h}^{-1}$ may be distinguished as concerns for both their variability and the $50 \%$ fractile (the $50 \%$-SRP related to $I_{30} \geq 44 \mathrm{~mm} \mathrm{~h}^{-1}$ shows a more marked "S shape"). From the remaining comparisons, only limited differences of the variability can be noticed. In addition, the following observations can be summarized:

- throughout the two decades of the observation period, the threshold $P_{\mathrm{EV}} \geq 100 \mathrm{~mm}$ was exceeded several times (903) on over the regional territory, and nine times in at least 20 rain gauges (Fig. 5a); this threshold was more frequently exceeded from November to January;

- by operating the selection shown in Fig. 5b, the threshold $I_{30} \geq 44 \mathrm{~mm} \mathrm{~h}^{-1}$ was exceeded six times in 20 or more rain gauges. Such threshold was more frequently exceeded from August to November;

- the threshold $E_{J} \geq 20 \mathrm{MJ} \mathrm{ha}^{-1}$ was exceeded nine times at a number of rain gauges greater than or equal to 20 (Fig. 5c); this threshold was more frequently exceeded from November to January.

The events exceeding these three thresholds are more frequent in the southern part and on the south-eastern side of Calabria (Fig. 5a-c). More precisely, with regards to the eventual interrelation between the characteristics of the SRP and the locations of the rain gauges, the comparisons between the SRP of events recorded in the lowest $(<600 \mathrm{~m}$ a.s.l.) and the highest $(\geq 600 \mathrm{~m}$ a.s.l.) elevation class and between the SRP of events occurred in the Ionian and Tyrrhenian homogeneous rainfall regions of Calabria show significant likenesses. Just a small variability may be attributed to the Ionian side of the region. Moreover, the comparison between rainfall profiles of events occurred in the four wettest and four driest months, reported in Fig. 6, highlights a lower variability for the wet season. In addition, advanced peaks characterize the storms of the dry season, in which convective events are more frequent.

\section{Method}

With the purpose of analysing the spatial and temporal characteristics of very severe rainstorms, a further selection of 

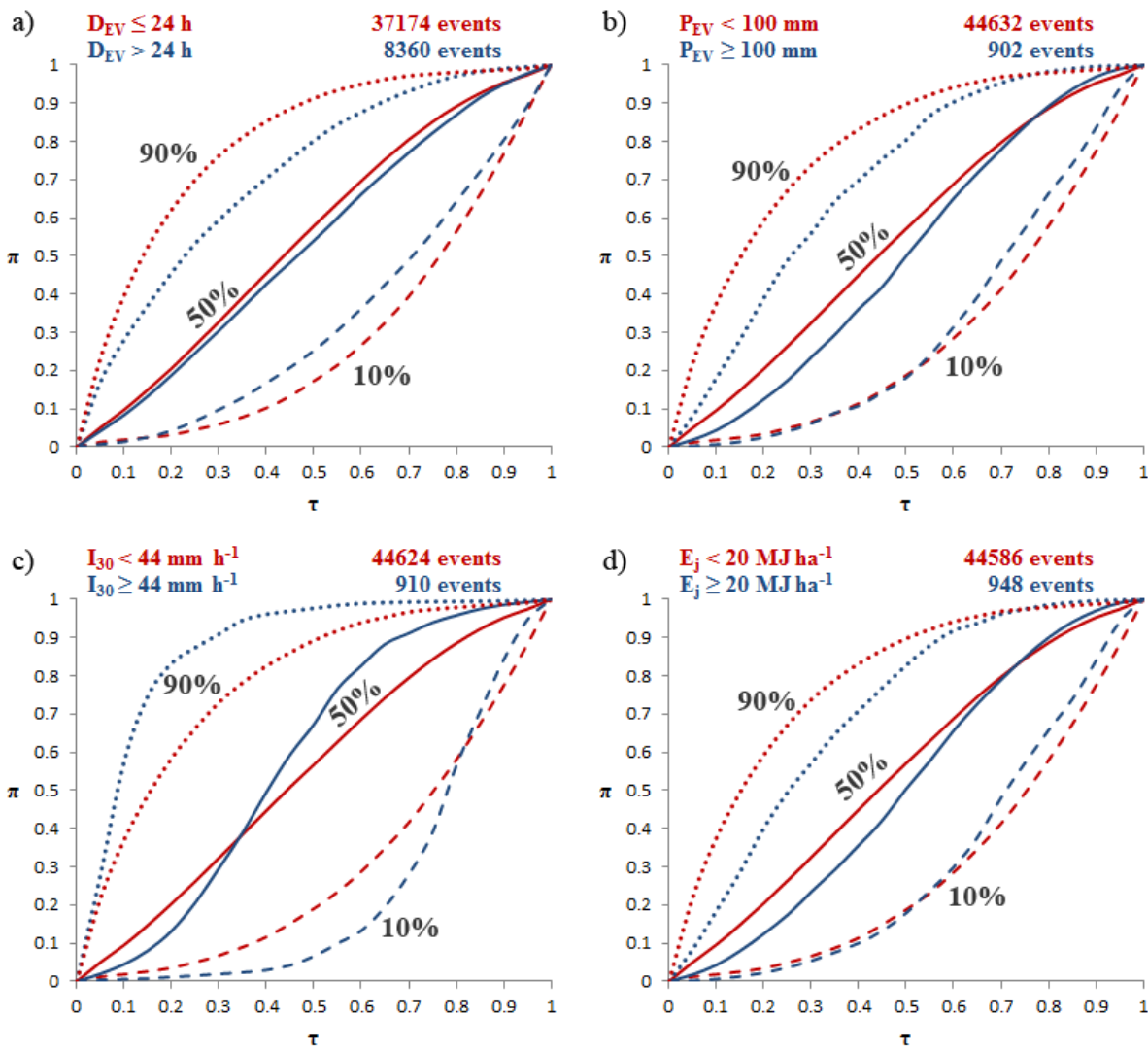

Figure 4. Comparison between SRP of the 45534 erosive events recorded in Calabria, distinguished by (a) $D_{\mathrm{EV}}$, (b) $P_{\mathrm{EV}}$, (c) $I_{30}$, and (d) $E_{J}$. The 90th, 50th, and 10th fractiles for each class are shown. On the horizontal axis, $\tau$ represents the cumulative fraction of the rainstorm time; on the vertical axis, $\pi$ represents the normalized cumulative depth of the rainstorm.

the events was conducted, based on the values of the parameters $P_{\mathrm{EV}}, I_{30}, E_{J}$. In this regard, to identify rainstorms with the greatest potential of producing a strong social impact and increase the perception of risk associated with the interaction between nature and society, it was assumed that the aforementioned parameters simultaneously satisfy the following constraints: $P_{\mathrm{EV}}>100 \mathrm{~mm} ; I_{30}>50 \mathrm{~mm} \mathrm{~h}^{-1}$; $E_{J}>29 \mathrm{MJ} \mathrm{ha}^{-1}$. The constraints on $P_{\mathrm{EV}}, I_{30}$, and $E_{J}$ were appropriately chosen on the base of both previous statistical analyses and other studies. For example, with reference to daily rainfall from 1951 to 1995 recorded at 265 rain gauges in the Mediterranean-climate regions (including 182 sites in Mediterranean-Spain, 42 in Italy, 3 in Cyprus and 38 in Israel), Alpert et al. (2002) selected six categories. In more detail, they proposed the following categories, in terms of power of two of the daily rainfall $\left(P_{\mathrm{D}}\right.$, in $\left.\mathrm{mm}\right)$ : light $(0-4)$, light-moderate (4-16), moderate-heavy (16-32), heavy (3264), heavy-torrential (64-128), and torrential (128-up). In order to determine the area hit by rainstorm events, Federico et al. (2008) classify an event as heavy rainfall if $P_{\mathrm{D}}>60 \mathrm{~mm}$ in at least one rain gauge, and $P_{\mathrm{D}}>20 \mathrm{~mm}$, for the same day, in at least 20 rain gauges. In this regard, the $60 \mathrm{~mm}$ value was chosen accordingly to analogous studies in the
Mediterranean area (Lana et al., 2007; Jansà et al., 2001) and in the MEDEX project (MEDiterranean EXperiment on cyclones that produce high impact weather in the Mediterranean, Buzzi et al., 2005). In the present investigation, the $60 \mathrm{~mm}$ value was increased to $100 \mathrm{~mm}$ in order to take into account the different time scale and context of interest. In fact, with reference to flash floods, Gaume et al. (2009) assume that, generally, local amounts greater than $100 \mathrm{~mm}$ in a few hours and covering areas of tens or, at most, a few hundred square kilometres must be considered. In the case of flash floods, as in the Mediterranean region, larger scale and longer lasting stationary rainstorms may occur, then a new criterion is proposed based on rainfall totalized in a short duration $(<24 \mathrm{~h})$ and the area $\left(<500 \mathrm{~km}^{2}\right)$ affected by the storm.

On the basis of the aforementioned constraints, several heavy rainstorm events (HREs), which occurred in Calabria during the observation period, were identified by considering the rainfall events recorded simultaneously at different rain gauges, even non-contiguous, within the region. In further detail, from the 37174 rainfall events with $D_{\mathrm{EV}} \leq 24 \mathrm{~h}$, the 137 having $P_{\mathrm{EV}} \geq 100 \mathrm{~mm}$ were distinguished. Next, 76 events having $I_{30} \geq 50 \mathrm{~mm} \mathrm{~h}^{-1}$ were extracted out of 

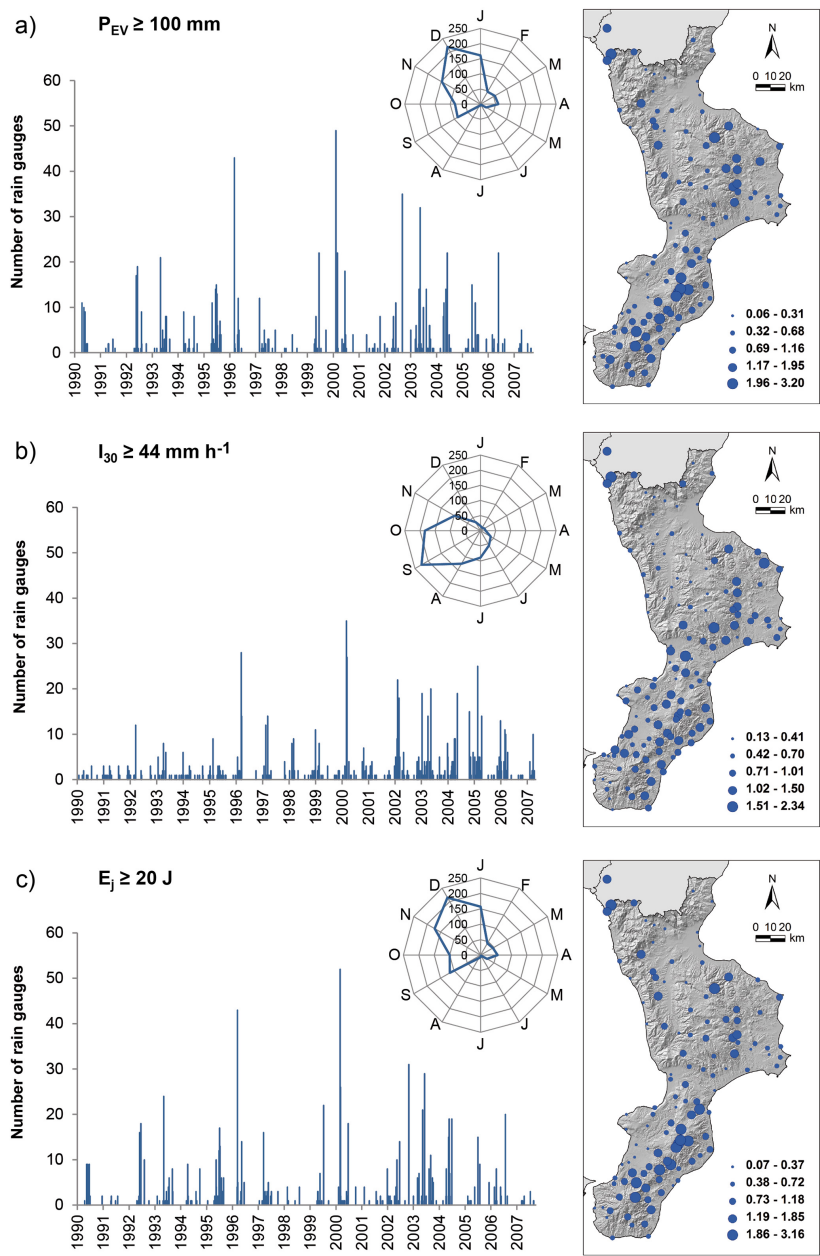

Figure 5. Rainfall events characterized by: (a) $P_{\mathrm{EV}} \geq 100 \mathrm{~mm}$; (b) $I_{30} \geq 44 \mathrm{~mm} \mathrm{~h}^{-1}$; (c) $E_{J} \geq 20 \mathrm{MJ} \mathrm{ha}^{-1}$. Timeline of the number of rain gauges that exceed the threshold value. The numerousness of events for each month is shown in the inset. The location and the ratio between numerousness of rainstorms and number of observation months for each rain gauge is shown in the map on the right.

these 137. Then, 49 out of these 76 events, having $E_{J} \geq$ $29 \mathrm{MJ} \mathrm{ha}^{-1}$, were picked out. Finally, from an examination of the times of occurrence of these 49 events, 25 distinct HREs could be identified, some of which occurred on the same dates at two or more rain gauges. Furthermore, regardless of the values of $D_{\mathrm{EV}}, I_{30}$ and $E_{J}$, those characterized by $P_{\mathrm{EV}} \geq$ $50 \mathrm{~mm}$ were selected and added to those that have already been used to determine the HREs. Thereby, the area struck by HREs (recorded in one or more rain gauges and having simultaneously $D_{\mathrm{EV}} \leq 24 \mathrm{~h}, P_{\mathrm{EV}} \geq 100 \mathrm{~mm}, I_{30} \geq 50 \mathrm{~mm} \mathrm{~h}^{-1}$ and $E_{J} \geq 29 \mathrm{MJ} \mathrm{ha}^{-1}$ ) was then increased by other areas affected by less severe, but still heavy, rainfall events (having $P_{\mathrm{EV}} \geq 50 \mathrm{~mm}$ ). In this regard, a reference area was indeed assigned at each rain gauge using the Thiessen polygons, allowing one to determine the portion of regional territory affected by each HRE. Therefore, the area struck by

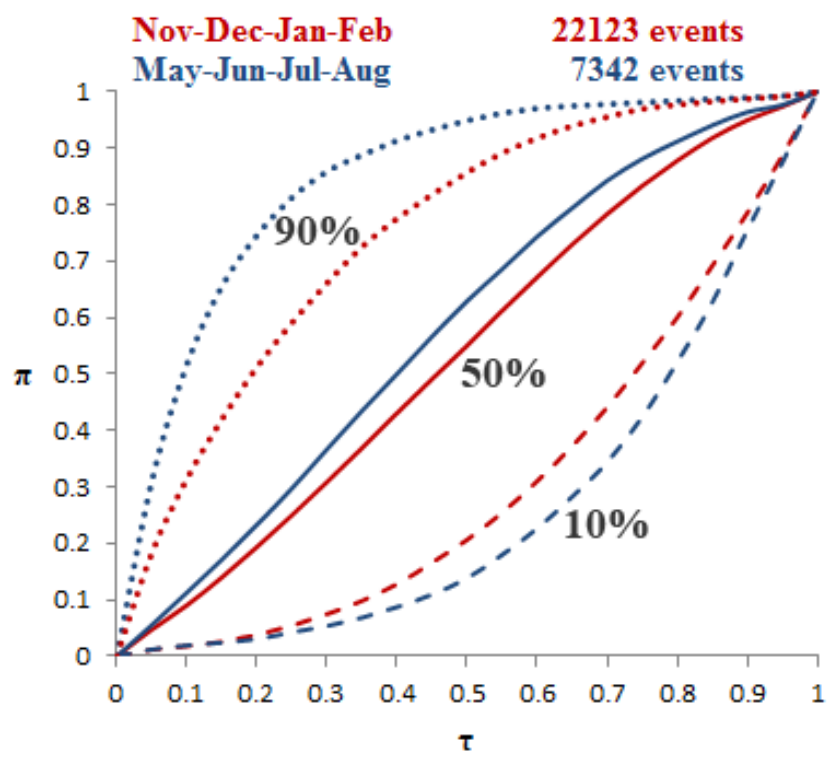

Figure 6. Comparison between the SRP of the events occurred during the four wettest and four driest months in Calabria. The 90th, 50th, and 10th fractiles for each class are shown. On the horizontal axis, $\tau$ represents the cumulative fraction of the rainstorm time; on the vertical axis, $\pi$ represents the normalized cumulative depth of the rainstorm.

widespread $\left({ }^{\mathrm{W}} \mathrm{HRE}\right)$ and localized ( $\left.{ }^{\mathrm{L}} \mathrm{HRE}\right)$ heavy rainstorm events was delimited and a spatial analysis was performed. More precisely, an HRE is defined as widespread (localized) if an area greater (smaller or equal) than $500 \mathrm{~km}^{2}$ is hit by a rainfall event. In both cases the aforementioned requirements have to be satisfied: (i) $P_{\mathrm{EV}} \geq 50 \mathrm{~mm}$ in all rain gauges, and (ii) $D_{\mathrm{EV}} \leq 24 \mathrm{~h}, P_{\mathrm{EV}} \geq 100 \mathrm{~mm}, I_{30} \geq 50 \mathrm{~mm} \mathrm{~h}^{-1}$, and $E_{J} \geq 29 \mathrm{MJ} \mathrm{ha}^{-1}$ in at least one rain gauge.

\section{Results and discussion}

Following an accurate description of the rainfall that hit Calabria, with special attention to the sub-hourly scale, a heuristic method was proposed to select and characterize the rainstorms that were capable of inducing flash floods and other physical processes to high impact on economic and social structure of the countries characterized by Mediterranean climate.

By applying the criteria mentioned in the previous paragraph, $17{ }^{\mathrm{W}}$ HREs and $8{ }^{\mathrm{L}}$ HREs were identified in Calabria, related to the period from 1989 to 2008 (Table 2). Wellknown catastrophic geo-hydrological events are included among these HREs.

The spatial features of the heavy rainstorms can be mapped, allowing some useful observations (Fig. 7a-i). Among the ${ }^{\mathrm{L}} \mathrm{HRE}$ events, that of 2 March 1996 has concerned only one station for an area of barely $57 \mathrm{~km}^{2}$ (Fig. 7a), confirming that these violent rainstorms can be extremely 


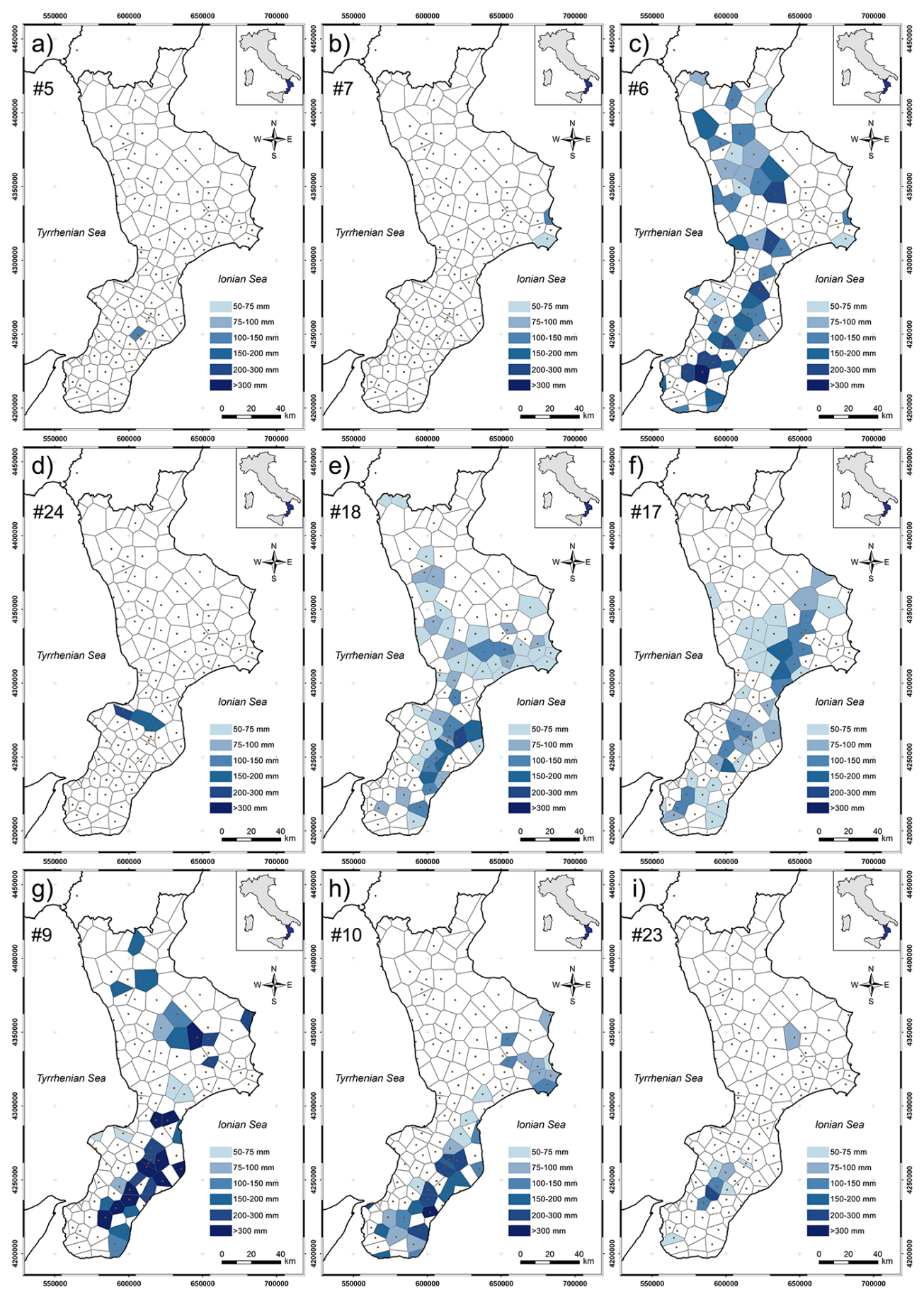

Figure 7. Spatial features of some significant, heavy rainstorms. Numbers in each map are referred to in Table 2. Brown points indicate the rain gauges in which the rainfall events that are used for determining the HRE are recorded. Thiessen polygons related to the 155 rain gauges are also shown and coloured according to the value of $P_{\mathrm{EV}}$. (a) ${ }^{\mathrm{L}} \mathrm{HRE}$ of 2 March 1996, affecting an area of $57 \mathrm{~km}{ }^{2}$. (b) ${ }^{\mathrm{L}} \mathrm{HRE}$,

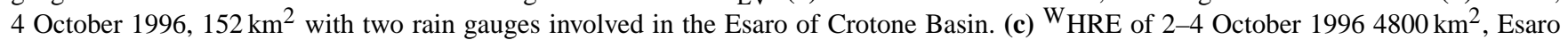
of Crotone and many other basins. (d) ${ }^{\mathrm{L}} \mathrm{HRE}, 3$ July $2006,270 \mathrm{~km}^{2}$ (3 rain gauges), Vibo Valentia flooding. (e) ${ }^{\mathrm{W}} \mathrm{HRE}, 6 \mathrm{March} 2004$, ca. $5100 \mathrm{~km}^{2}$ (56 rain gauges). (f) ${ }^{W_{H R E}}, 25$ November 2003 (44 rain gauges, $4550 \mathrm{~km}^{2}$ ). (g) ${ }^{\mathrm{W}}$ HRE, $7-10$ September 2000 north-eastern and

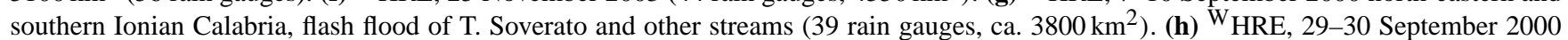
(ca. $2800 \mathrm{~km}^{2}$ in 39 rain gauges). (i) ${ }^{\mathrm{W}}$ HRE, 22 October 2005 (9 rain gauges, ca. $714 \mathrm{~km}^{2}$ ), with the maximum value of $I_{30}\left(154.8 \mathrm{~mm} \mathrm{~h}^{-1}\right)$. 
Table 2. Features of the determined HREs. Key: Max $D_{\mathrm{EV}}$, Min $D_{\mathrm{EV}}$, Max $E_{j}$, Max $I_{30}$, are referred to the events that constitute each HRE; Type $=$ type of HRE $(\mathrm{L}=$ localized HRE, $\mathrm{W}=$ widespread HRE $) ; \#_{100}=$ number of rain gauges with $P_{\mathrm{EV}} \geq 100 \mathrm{~mm}$; $\#_{50}=$ number of rain gauges with $50 \leq P_{\mathrm{EV}}<100 \mathrm{~mm}$; Area $=$ area affected by each $\mathrm{HRE}$, evaluated by means of the Thiessen polygons; ${ }^{\mathrm{AV}} P_{\mathrm{EV}}=\mathrm{areal}$ average of the rainstorm amount. Maximum values of each column are in bold and minimum values are in italics. The maps of Figs. 7 and 8 describe some of these HREs.

\begin{tabular}{|c|c|c|c|c|c|c|c|c|c|c|c|}
\hline Event no. & Type & Starting date & Ending date & $\begin{array}{l}\operatorname{Max} D_{\mathrm{EV}} \\
{[\mathrm{min}]}\end{array}$ & $\begin{array}{l}\operatorname{Min} D_{\mathrm{EV}} \\
{[\mathrm{min}]}\end{array}$ & $\#_{100}$ & $\#_{50}$ & $\begin{array}{l}\text { Area } \\
{\left[\mathrm{km}^{2}\right]}\end{array}$ & $\begin{array}{l}{ }^{\mathrm{AV}} P_{\mathrm{EV}} \\
{[\mathrm{mm}]}\end{array}$ & $\begin{array}{l}\operatorname{Max} E_{J} \\
{\left[\mathrm{MJ} \mathrm{ha}^{-1}\right]}\end{array}$ & $\begin{array}{l}\operatorname{Max} I_{30} \\
{\left[\mathrm{~mm} \mathrm{~h}^{-1}\right]}\end{array}$ \\
\hline 1 & $\mathrm{~L}$ & 12-Oct-91 & 13-Oct-91 & 1400 & 1025 & 1 & 1 & 130.8 & 149.2 & 46.2 & 69.6 \\
\hline 2 & $\mathrm{~L}$ & 04-Jan-93 & 05-Jan-93 & 1340 & 855 & 2 & 3 & 445.6 & 87.2 & 84.4 & 31.5 \\
\hline 3 & $\mathrm{~L}$ & 06-Nov-94 & 06-Nov-94 & 955 & 720 & 2 & 1 & 215.5 & 159.1 & 61.7 & 81.6 \\
\hline 4 & W & 12-Mar-95 & 15-Mar-95 & 3300 & 815 & 8 & 19 & 2556.4 & 90.9 & 42.0 & 62.4 \\
\hline 5 & $\mathrm{~L}$ & 02-Mar-96 & 03-Mar-96 & 300 & 300 & 1 & 0 & 57.1 & 149.2 & 39.8 & 72.4 \\
\hline 6 & W & 02-Oct-96 & $05-$-Oct-96 & 4215 & 625 & 35 & 14 & 4795.8 & 136.4 & 86.8 & 101.2 \\
\hline 7 & $\mathrm{~L}$ & 14-Oct-96 & 14-Oct-96 & 440 & 360 & 1 & 1 & 151.9 & 61.2 & 106.0 & 29.4 \\
\hline 8 & W & 23-Sep-97 & 25-Sep-97 & 1350 & 765 & 3 & 7 & 905.8 & 68.2 & 72.4 & 31.9 \\
\hline 9 & W & 07-Sep-00 & 11-Sep-00 & 4590 & 590 & 32 & 7 & 3780.2 & 237.1 & 116.6 & 144.4 \\
\hline 10 & $\mathrm{~W}$ & 29-Sep-00 & 01-Oct-00 & 2615 & 630 & 22 & 14 & 2808.4 & 139.9 & 115.2 & 143.6 \\
\hline 11 & W & 13-Jan-01 & 15-Jan-01 & 1435 & 1105 & 3 & 7 & 747.6 & 84.9 & 66.4 & 29.1 \\
\hline 12 & W & 05-May-01 & 07-May-01 & 3210 & 490 & 4 & 14 & 1353.1 & 76.7 & 36.7 & 99.2 \\
\hline 13 & $\mathrm{~L}$ & 01-Sep-02 & 02-Sep-02 & 280 & 265 & 1 & 2 & 314.1 & 87.0 & 112.8 & 32.1 \\
\hline 14 & W & 21-Nov-02 & 21-Nov-02 & 1045 & 275 & 3 & 16 & 2053.9 & 69.9 & 60.4 & 32.6 \\
\hline 15 & W & 14-Oct-03 & 24-Oct-03 & 14690 & 145 & 5 & 8 & 1177.4 & 98.2 & 58.4 & 99.6 \\
\hline 16 & W & 22-Nov-03 & 22-Nov-03 & 550 & 335 & 2 & 5 & 575.6 & 83.2 & 37.3 & 72.8 \\
\hline 17 & W & 25-Nov-03 & 27-Nov-03 & 2370 & 640 & 14 & 30 & 4550.3 & 88.1 & 47.6 & 91.2 \\
\hline 18 & $\mathrm{~W}$ & 06-Mar-04 & 10-Mar-04 & 5185 & 945 & 14 & 42 & 5219.4 & 85.3 & 50.7 & 53.6 \\
\hline 19 & $\mathrm{~L}$ & 20-Sep-04 & 20-Sep-04 & 765 & 270 & 1 & 3 & 472.3 & 92.5 & 35.8 & 114.8 \\
\hline 20 & $\mathrm{~W}$ & 03-Nov-04 & 05-Nov-04 & 2615 & 885 & 8 & 17 & 2254.1 & 94.0 & 43.4 & 104.0 \\
\hline 21 & W & 11-Nov-04 & 14-Nov-04 & 4565 & 575 & 11 & 14 & 2896.8 & 106.4 & 59.7 & 126.0 \\
\hline 22 & W & 08-Dec-04 & 11-Dec-04 & 3185 & 495 & 11 & 22 & 3012.7 & 91.3 & 62.4 & 92.0 \\
\hline 23 & W & 22-Oct-05 & 23-Oct-05 & 990 & 280 & 3 & 6 & 713.7 & 97.9 & 61.1 & 154.8 \\
\hline 24 & $\mathrm{~L}$ & 03-Jul-06 & 03-Jul-06 & 550 & 305 & 3 & 0 & 271.4 & 186.8 & 56.1 & 137.6 \\
\hline 25 & W & 25-Sep-06 & 26-Sep-06 & 1365 & 180 & 2 & 11 & 1294.5 & 72.7 & 132.0 & 29.1 \\
\hline
\end{tabular}

localized. Another ${ }^{\mathrm{L}} \mathrm{HRE}$, that of 14 October 1996, affecting an area of about $152 \mathrm{~km}^{2}$ and two rain gauges (Fig. 7b), corresponds to the flash flood of the river Esaro of Crotone that caused 6 deaths and wiped out many industrial and commercial buildings (damage was estimated at ca. EUR 70 million). It is worth mentioning that this ${ }^{\mathrm{L}} \mathrm{HRE}$, characterized by high $I_{30}$ but not by a very high $P_{\mathrm{EV}}$, was preceded by the ${ }^{\mathrm{W}} \mathrm{HRE}$ which occurred on 2-4 October 1996, with $P_{\mathrm{EV}}$ greater than $300 \mathrm{~mm}$, and extended approximately $4800 \mathrm{~km}^{2}$ in the same basin and in other areas of Calabria (Fig. 7c). The ${ }^{\mathrm{L}} \mathrm{HRE}$ that occurred on 3 July 2006 struck an area of approximately $270 \mathrm{~km}^{2}$ (3 rain gauges, Fig. 7d), causing four casualties as a result of the flash floods in the Sant'Anna torrent and in some small streams that crossed the town of Vibo Valentia.

On the other hand, some widespread events were those of 6 March 2004, with approximately $5100 \mathrm{~km}^{2}$ (56 rain gauges; Fig. 7e), of 25 November 2003 (44 rain gauges, $4550 \mathrm{~km}^{2}$; Fig. 7f), and of 7-10 September 2000 (Fig. 7g). This last event has affected the Ionian Calabria, with tragic effects in the southern part, where the flash flood of the torrent Soverato caused the death of 13 people (39 rain gauges, approximately $3800 \mathrm{~km}^{2}$; Fig. $7 \mathrm{~g}$ ). Also, in other neighbouring $f$ umare (e.g. Allaro, Amusa, Precariti, Barone, Carciamite, Vatrò, San Giorgio, Guardavalle, Stilaro, Alatro and Portigliola, cf. Fig. 1) disastrous flash floods occurred, with a strong socio-economic impact, but fortunately without further casualties. Unfortunately, this ${ }^{\mathrm{W}}$ HRE was followed after only 20 days by that of the 29-30 September 2000 (extended about $2800 \mathrm{~km}^{2}, 39$ rain gauges; Fig. 7h) which caused further damage in approximately the same area. Detailed historical information about these geo-hydrological catastrophic events can be found in Gabriele (1998), Antronico et al. (2002), Sorriso-Valvo et al. (2004), Iovine et al. (2009).

With regards to the temporal properties of the heavy localized and widespread rainstorms, some of their SRPs are reported in the insets of Fig. 8a-f. At stations with $P_{\mathrm{EV}} \geq$ $100 \mathrm{~mm}$, many events (see Fig. 8c-f, corresponding to events no. 10, 24, 18, and 17 in Table 2) have the typical structure of tropical-like cyclones in the Mediterranean Sea (medicanes). In most of the stations, event no. 17 (Fig. 7f, 8f, Table 2) shows a structure close to the BSC 0011 type. Even for the event no. 12 (Fig. 8a), occurred on 5 May 2001, results that an ${ }^{\mathrm{W}}$ HRE described by a single type of profile (BSC 1111, thunderstorm, as reported in Fig. 2) has invested a wide areas of the Serre mountain range and limited portions of the Aspromonte and Sila Massifs. The structure of event no. 24 (Figs. 7d, 8d) is rather different from station to station, making the non-frequent meteorological features of this rainstorm evident. Although other situations are more complex, it is possible to relate (e.g. event no. 18, Figs. 7e, 8e) the spatial distribution of the structure of the SRP to the regional orography, to the incoming direction of perturbations and to the quantities given in the maps of Fig. 8a-f. 


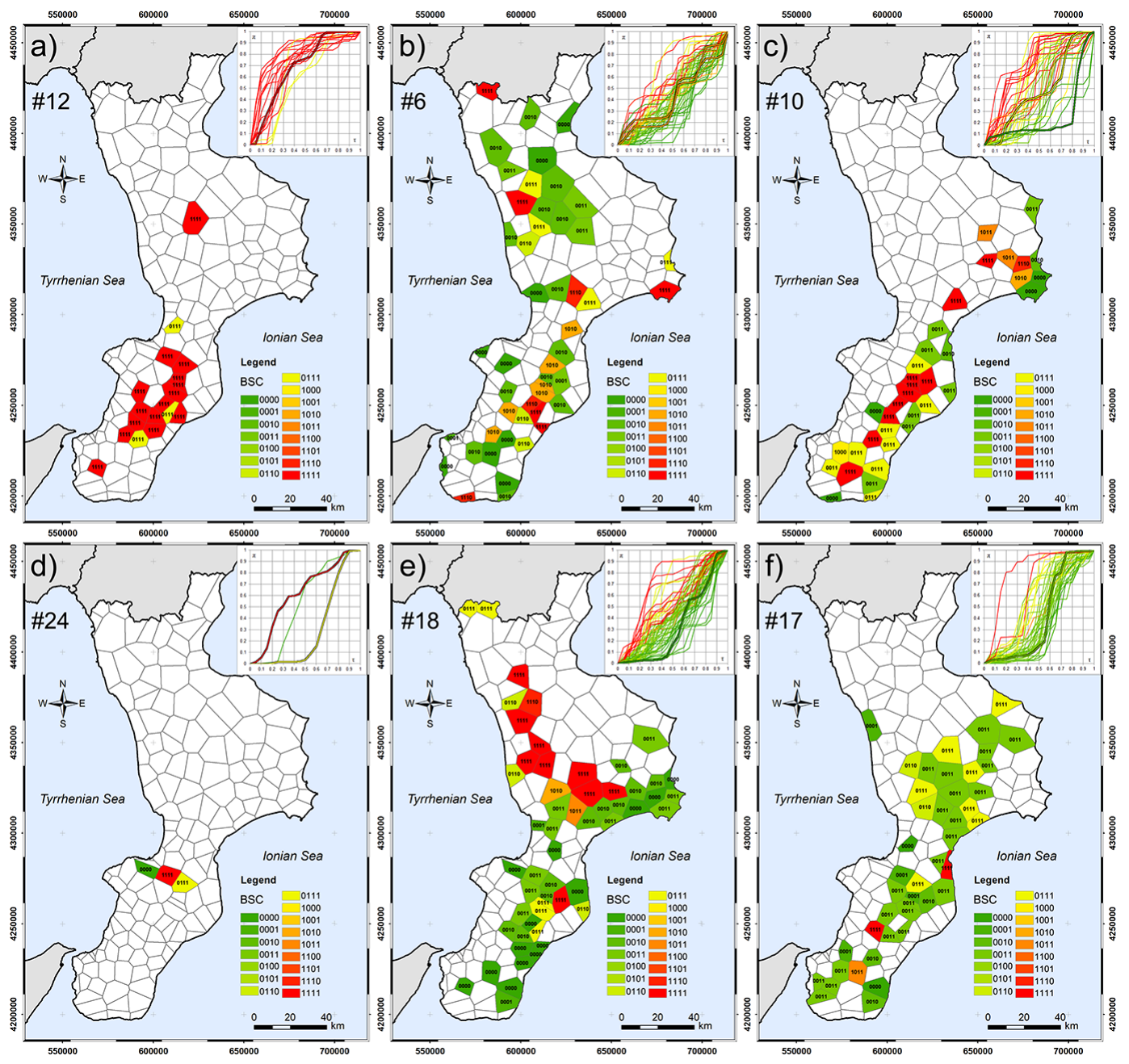

Figure 8. Spatial distribution of some HREs in Calabria, according to the Thiessen polygon delimitation and their binary shape code (BSC). The standard rainfall profiles (SRP), distinguished according to the BSC, are reported in the insets. The more marked SRPs are those related to events with $D_{\mathrm{EV}} \leq 24 \mathrm{~h}, P_{\mathrm{EV}} \geq 100 \mathrm{~mm}, I_{30} \geq 50 \mathrm{~mm} \mathrm{~h}^{-1}$ and $E_{J} \geq 29 \mathrm{MJ} \mathrm{ha}^{-1}$. Numbers indicate the events reported in Table 2 .

\section{Conclusions}

Adopting an automatic and reproducible procedure, 25 heavy rainstorm events with different characteristics were identified in Calabria, throughout the period from 1989 to 2008, including some catastrophic events. Spatial features and temporal structures of those events were analysed and shown. Catastrophic events have different spatial extents and temporal patterns; damages are not connected with a greater spatial extent (cf. e.g. events no. 7, 9 and 24). In fact, the environmental (e.g. orography) and anthropic (e.g. urbanization and density of infrastructure) characteristics also play a relevant role in causing damage and fatalities. Generally, localized events (e.g. Fig. 8a) have temporal structures with the peak at the beginning of the event (thunderstorm-type, BSC $=1111$ ). On the contrary, wide events have mixed temporal structures (e.g. Fig. 8b, c, e), with peaks localized at the second half of the Huff's curves (BSC from 0000 to 0100).
The employed database includes information characterized by a notable size of the sample, a detailed resolution in time, along with a dense network of rain gauges, determining a good robustness of the obtained results.

The application conducted in Calabria (a region representative for climate and morphological conditions of wider Mediterranean areas) has allowed the verification of the validity of the proposed method for the events that have hit heavily areas more or less extensively on this territory in recent decades. As mentioned, well-known catastrophic geohydrological events are included among the analysed HRE, whose high frequency, over time ( 25 heavy rainstorms in 20 years), shows that this physical phenomena has a great social and economic impact for Calabria.

The proposed method improves the knowledge regarding the input of rainfall-runoff watershed models. The identification of design storms - made using an automatic classification of the rainfall profiles -, with a realistic time structure, 
was integrated with the results of the spatial analysis. In fact, the sectors of the region more frequently affected by the most severe rain events (in terms of $P_{\mathrm{EV}}, I_{30}, E_{J}$ ) were picked out in relation to their time structure. The implementation of computer tools that generate the most stringent design storms at random but based on SRP realistic (i.e. characterized by BSC, $D_{\mathrm{EV}}, P_{\mathrm{EV}}, I_{30}, E_{J}$ peculiar to certain sites/basins) is therefore facilitated. In particular, by properly integrating the proposed method into a model of flood forecasting and rainfall-runoff models, streams that are more frequently subject to flash floods can be kept under control.

Acknowledgements. We thank the Calabrian Regional Agency for Environmental Protection (ARPACAL) for access to rainfall data. We acknowledge the anonymous referees for their constructive comments.

Edited by: M.-C. Llasat

Reviewed by: three anonymous referees

\section{References}

Alpert, P., Ben-Gai, T., Baharad, A., Benjamini, Y., Yekutieli, D., Colacino, M., Diodato, L., Ramis, C., Homar, V., Romero R., Michaelides S., and Manes A.: The paradoxical increase of Mediterranean extreme daily rainfall in spite of decrease in total values, Geophy. Res. Lett., 29, 31-1-31-4, 2002.

Antronico, L., Gullà, G., and Terranova, O.: L'evento pluviometrico dell' $8-10$ settembre 2000 nella Calabria Ionica meridionale: dissesti sui versanti e processi in alveo, Proc. of "Il Dissesto Idrogeologico: Inventario e Prospettive", Accademia Nazionale dei Lincei, Rome 05-06-2001, 67-79, 2002 (in Italian).

Brunetti, M., Buffoni, L., Mangianti, F., Maugeri, M., and Nanni, T.: Temperature, precipitation and extreme events during the last century in Italy, Global Planet. Change, 40, 141-149, 2004.

Brunetti, M., Caloiero, T., Coscarelli, R., Gullà, G., Nanni, T., and Simolo, C.: Precipitation variability and change in the Calabria region (Italy) from a high resolution daily dataset, Int. J. Climatol., 32, 57-73, 2012.

Buzzi, A., Richard, E., Romero, R.: Summary report on MEDEX studies and scientific results on Mediterranean cyclones causing high impact weather in the Mediterranean, 2005, Report on scientific results, available at: http://medex.aemet.uib.es/ documents/Summary_on_MEDEX_studies_Nov05.pdf.

Collier, C.: Flash flood forecasting: What are the limits of predictability?, Q. J. Roy. Meteor. Soc., 133, 3-23, 2007.

Colosimo, C., Mendicino, G., and Terranova, O.: An analysis of rainfall profiles of an experimental basin (Turbolo creek basinItaly), in Proc. of the Conferencia Internacional de Geologia Ambiental y Ordenacion del territorio, Granada, Spain, 22-25 April 1996, 173-186, 1996.

Creutin, J. D. and Borga, M.: Radar hydrology modifies the monitoring of flash flood hazard, Hydrol. Process., 17, 1453-1456, 2003.

Creutin, J. D., Borga, M., Lutoff, C., Scolobig, A., Ruin, I., and Créton-Cazanave, L.: Catchment dynamics and social response during flash floods: the potential of radar rainfall monitoring for warning procedures, Meteorol. Appl., 16, 115-125, 2009.

Fairbridge, R.W.: The Encyclopedia of Geomorphology, Reinhold Book Corporation, New York, 1295 pp., 1968.

Federico, S., Avolio, E., Bellecci, C., Lavagnini, A., Colacino, M., and Walko, R. L.: Numerical analysis of an intense rainstorm occurred in southern Italy, Nat. Hazards Earth Syst. Sci., 8, 1935, doi:10.5194/nhess-8-19-2008, 2008.

Gabriele, S.: Crotone e l'evento alluvionale del 14-10-1996, GNDCI pubbl. 1891, Cosenza, Italy, 114 pp., 1998 (in Italian).

Gaume, E., Bain, V., Bernardara, P., Newinger, O., Barbuc, M., Bateman, A., Blaskoviovă, L., Bloschl, G., Borga, M., Dumitrescu, A., Daliakopoulos, I., Garcia, J., Irimescu, V., Kohnova, S., Koutroulis, A., Marchi, L., Matreata, S., Medina, V., Preciso, E., Sempere-Torres, D., Stancalie, G., Szolgay, J., Tsanis, I., Velasco, D., and Viglione, A.: A compilation of data on European flash floods, J. Hydrol., 367, 70-78, 2009.

Huff, F. A.: Time distribution of rainfall in heavy storms, Water Resour. Res., 3, 1007-1019, 1967.

Huff, F. A.: Time distributions of heavy rain storms in Illinois. Illinois State Water Survey, Champaign, Circular, 173 pp., 1990.

Houze, R. A.: Characteristics of Mesoscale Precipitation Areas. S.M. Thesis, Dept. of Meteorology, Massachusetts Institute of Technology, Cambridge, MA, 77 pp., 1969.

Iaquinta, P. and Terranova, O.: Lineamenti climatici e termometrici della Calabria: classificazione climatica di Köppen mediante sistemi GIS e Geoprocessing, in: Relazione finale "Pericolosità legata ai fenomeni di intensa erosione idrica areale e lineare", edited by: Terranova, O., POR Calabria 2000-2006, Azione. 1.4c, lotto 2. CNR-IRPI, Cosenza, Italy, A1-A18 pp., 2010 (in Italian).

Iovine, G., Gariano, S. L., and Terranova, O.: Alcune riflessioni sull'esposizione al rischio da frane superficiali alla luce dei recenti eventi in Italia meridionale, Geologi Calabria, 10, 4-31, 2009 (in Italian).

Jansà, A., Radinovic, D., Alpert, P., Genovés, A., Campins, J., and Picornell, M. A.: Mediterranean cyclones: Subject of a WMO Project, Internat. Symposium on the Life Cycle of Extratropical Cyclones, Bergen, Vol. II, 26-31, 1994.

Jansà, A., Genovés, A., Picornell, M. A., Campins, J., Riosalido, R., and Carretero, O.: Western Mediterranean cyclones and heavy rain. Part 2: Statistical approach, Meteorol. Appl., 8, 43-56, 2001.

Joo, J., Lee, J., Kim, J. H., Jun, H., and Jo, D.: Inter-Event Time Definition Setting Procedure for Urban Drainage Systems, Water, 6, 45-58, 2014.

Köppen, W.: Climatologia, con un estudio de los climas de la tierra, Fondo de Cultura Economica, Mexico, 479 pp., 1948.

Lana, A., Campins, J., Genovés, A., and Jansà, A.: Atmospheric patterns for heavy rain events in the Balearic Islands, Adv. Geosci., 12, 27-32, doi:10.5194/adgeo-12-27-2007, 2007.

Lionello, P., Malanotte-Rizzoli, P., and Boscolo, R.: Mediterranean climate variability, Elsevier, Amsterdam, 438 pp., 2006.

Moore, R. J., Bell, V. A., and Jones, D. A.: Forecasting for flood warning, C. R. Geosci., 337, 203-217, 2005.

Munich RE: Topics Geo. Natural catastrophes 2013: analyses, assessments, positions, Munich Reinsurance Company, 65 pp., 2014. 
Piervitali, E., Colacino, M., and Conte, M.: Rainfall over the central-western Mediterranean basin in the period 1951-1995. Part I: precipitation trends, Nuovo Cimento C, 21, 331-344, 1998.

Restrepo-Posada, P. J. and Eagleson, P. S.: Identification of independent rainstorms, J. Hydrol., 55, 303-319, 1982.

Siccardi, F.: Rainstorm hazards and related disasters in the western Mediterranean region, Rem. Sens. Rev., 14, 5-21, 1996.

Sorriso-Valvo, G. M., Antronico, L., Gaudio, R., Gullà,G., Iovine, G., Merenda, G., Minervino, I., Nicoletti, P. G., Petrucci, O., and Terranova, O.: Carta dei dissesti causati in Calabria meridionale dall'evento meteorologico dell' $8-10$ settembre 2000, CNR-GNDCI pubbl. 2859, Rubbettino, Soveria Mannelli, Italy, 2004 (in Italian).

Sorriso-Valvo, G. and Terranova, O.: The Calabrian fiumara streams. Zeitschrift für Geomorphologie, Land Degradation, Supplement, 143, 109-125, 2006.

Terranova, O.: Caratteristiche degli eventi pluviometrici a scala giornaliera in Calabria, Proc. of XXIX Convegno di Idraulica e Costruzioni Idrauliche, Trento 7-10/09/2004, EdiBios, Cosenza, ISBN 88-7740-382-9, 2, 343-350, 2004 (in Italian).
Terranova, O. G. and Iaquinta, P.: Temporal properties of rainfall events in Calabria (southern Italy), Nat. Hazards Earth Syst. Sci., 11, 751-757, doi:10.5194/nhess-11-751-2011, 2011.

Terranova, O., Antronico, L., Coscarelli, R., and Iaquinta, P.: Soilerosion risk scenarios in the Mediterranean environment using RUSLE and GIS: an application model for Calabria (southern Italy), Geomorphology, 112, 228-245, 2009.

Versace, P., Ferrari, E., Gabriele, S., and Rossi, F.: Valutazione delle piene in Calabria, Geodata, 30. CNR IRPI, Cosenza, Italy, 220 pp., 1989 (in Italian).

Wischmeier, W. H. and Smith, D. D.: Predicting rainfall erosion losses - A guide to conservation planning, Agricultural Handbook 537, USDA, Agricultural Research Service, Washington DC, 58 pp., 1978.

Younis, J., Anquetin, S., and Thielen, J.: The benefit of highresolution operational weather forecasts for flash flood warning, Hydrol. Earth Syst. Sci., 12, 1039-1051, doi:10.5194/hess-121039-2008, 2008. 